\title{
Long-term destruction of sub-arctic wetland vegetation by lesser snow geese
}

Post-print/Accepted manuscript

Peter M. Kotanen

Robert L. Jefferies

Peter M. Kotanen \& Robert L. Jefferies (1997) Long-term destruction of subarctic wetland vegetation by lesser snow geese, Écoscience, 4:2, 179-182 doi: 10.1080/11956860.1997.11682393

The Version of Record of this manuscript has been published and is available in Écoscience 4 (1997) http://www.tandfonline.com/doi/abs/10.1080/11956860.1997.11682393

\section{HOW TO CITE TSPACE ITEMS}

Always cite the published version, so the author(s) will receive recognition through services that track citation counts, e.g. Scopus. If you need to cite the page number of the TSpace version (original manuscript or accepted manuscript) because you cannot access the published version, then cite the TSpace version in addition to the published version using the permanent URI (handle) found on the record page. 


\title{
Long-term destruction of sub-arctic wetland vegetation by lesser snow geese
}

\author{
Peter Kotanen * \\ Department of Ecology and Evolution \\ University of Chicago \\ 1101 E 57th Street \\ Chicago, Illinois, USA 60637 \\ and \\ R.L. Jefferies $\dagger$ \\ Department of Botany \\ University of Toronto \\ 25 Willcocks Street \\ Toronto, Ontario, Canada M5S 3B2 \\ *Current address: Department of Botany \\ Erindale College, University of Toronto \\ 3359 Mississauga Road North \\ Mississauga, Ontario, Canada L5L 1C6
}

†Correspondence

author 
Kotanen \& Jefferies: Long-term destruction by geese

\begin{abstract}
During the last two decades, the mid-continent population of lesser snow geese (Anser caerulescens caerulescens), which breeds in the Canadian eastern Arctic, has increased dramatically to at least 3 million birds. In spring, the birds follow the retreating snowline northwards to the breeding grounds. They forage intensively on shoots of sedges just south of the snowline, eating the swollen shoot bases and discarding the remainder. Exclosures were established in 1985/86 at La Pérouse Bay, Manitoba to determine the effects of protection from foraging on the shoot densities of sedges. Between 1986 and 1995, numbers of shoots increased from 1.1 to 2.2 times in exclosed plots, while numbers in grazed plots declined to between 0.19 and 0.33 times their original values. Sedge assemblages were replaced by moss carpets or standing water rich in peat debris. The ecological significance of the results is discussed in relation to re-establishment of vegetation and the role of herbivores in changing species assemblages.
\end{abstract}

Keywords: herbivory, shoot-pulling, sedges, moss carpets, alternative vegetation states. 
Kotanen \& Jefferies: Long-term destruction by geese

\section{Introduction}

Populations of a herbivorous bird, the lesser snow goose (Anser caerulescens caerulescens L.) have increased dramatically in recent decades in the mid-continent region of North America. The current population size is at least 3 million birds (Abraham et al., 1996), and the rate of increase in population numbers is in the order of $7 \%$ per annum (Cooke, Rockwell \& Lank, 1995). The increase is thought to be related to the use of agricultural land as a source of forage on wintering grounds and along flyways (Hobaugh, Stutzenbaker \& Flickinger, 1989; Alisaukas \& Ankney, 1992; Robertson \& Slack, 1995) which, in effect, provide an energy and nutrient subsidy to geese (Abraham et al., 1996).

At one breeding colony, at La Pérouse Bay on the Hudson Bay coast, numbers of lesser snow geese have increased from just under 2000 pairs in 1968 (Cooke, Rockwell \& Lank, 1995) to an estimated 23000 pairs in 1990 (Kerbes, unpub. photographic inventory). Such a large increase in numbers may be expected to lead to dramatic changes in the vegetation in the area. When the birds migrate north in spring to this site and to other breeding colonies in the Hudson Bay region, they follow the retreating snowline northwards. Often thousands of staging birds feed on vegetation immediately south of the snowline. The birds forage intensively on shoots of fresh-water sedges, particularly Carex aquatilis, before growth of shoots has commenced (Jefferies, 1988a,b). A shoot is pulled from its base, the swollen basal portion, which is rich in soluble carbohydrates and total nitrogen, is eaten (Gadallah \& Jefferies, 1995), and the remainder of the shoot is discarded. This type of foraging activity occurs annually in spring, but its intensity at a given site depends upon the uncertainties of weather and position of the snowline in any 
Kotanen \& Jefferies: Long-term destruction by geese

particular year. Over successive years the cumulative removal of vegetative and reproductive shoots of these sedges may be predicted to lead to significant changes in the species composition of the vegetation. In order to detect such changes, a series of exclosures from which geese were excluded were set up in 1985/86 at La Pérouse Bay in fresh-water ponds and in sedge meadow habitats $0.5 \mathrm{~km}$ inland from the coastal salt marshes. In 1986, 1989 and 1995, comparisons of shoot densities were made between exclosures and permanent quadrats in which shoots were unprotected from the effects of foraging.

\section{Material \& methods}

Study site

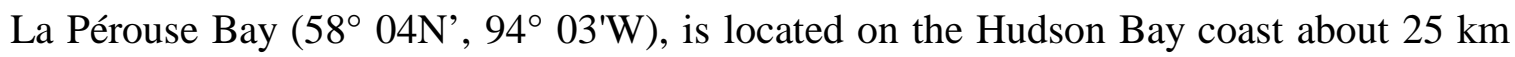
east of Churchill, Manitoba. Inland from the upper limit of spring tides, the landscape consists of a mosaic of fresh-water ponds, areas of saturated moss, and graminoid communities dominated by Carex species. Carex aquatilis ${ }^{1}(50 \mathrm{~cm}-1 \mathrm{~m}$ tall) frequently forms dense stands in standing water and permanently saturated ground. Smaller sedges (30 cm tall) that include Carex atrofusca, C. capillaris, ש. flavicans, C. microglochin, C. rariflora and C. vaginata grow in shallow water and in saturated carpets of moss (mostly Drepanocladus uncinatus and Aulacomnium species) that surround many ponds. On frost-heave mounds between ponds, the vegetation is dominated by shrubs that include Salix candida, S. lanata, S. planifolia, Betula glandulosa, Myrica gale and Empetrum nigrum. Since the mid-1980's, the density of nests of lesser snow geese in this 
Kotanen \& Jefferies: Long-term destruction by geese

area has been one of the highest on the Cape Churchill peninsula, approaching 2000 nests

$\mathrm{km}^{-2}$. Geese have used the vegetation as a primary source of forage during the periods of nest initiation and incubation from late May to early June, before the above-ground growth of sedge leaves commences.

\section{Exclosures}

In 1985 and 1986 a series of 30 exclosures was established in the Carex-dominated freshwater sites used by geese. Some shoot-pulling had occurred prior to the spring of 1985 (pers. observ.) at these sites. The exclosures were established for various purposes (Kotanen \& Jefferies, 1989a,b). They were either $0.5 \mathrm{~m} \mathrm{x} 0.5 \mathrm{~m}$ (small) or $4 \mathrm{~m}$ x $5 \mathrm{~m}$ (large); all were constructed with chicken wire $(2.5 \mathrm{~cm}$ mesh size, $50 \mathrm{~cm}$ high) stapled to wooden stakes anchored in the ground. The 30 exclosures were distributed along a belt transect $1 \mathrm{~km}$ in length and $200 \mathrm{~m}$ wide. Exclosures were at least $50 \mathrm{~m}$ apart. Two types of sedge assemblage were protected: those dominated by stands of Carex aquatilis and those dominated by small sedges, of which एarex flavicans was the most abundant. Adjacent, unexclosed plots were also set up within 5 metres of each exclosure.

In 1986, 1989 and 1995 growing shoots were counted in subplots within each exclosure and within the immediately adjacent, unexclosed plots. Observers, number of plots located, and total area sampled varied in the three years, as discussed below (Table I). All recordings of shoot densities were made in June. A consequence of having multiple observers was that different exclosures were sampled in different years. Most (>

${ }^{1}$ Nomenclature Follows Scoggan (1978). 
Kotanen \& Jefferies: Long-term destruction by geese

75\%) of the exclosures sampled in 1986 were small (< $1 \mathrm{~m})$, while those sampled in 1989 were larger (> $1 \mathrm{~m}$ ); a full size range was sampled in 1995 .

Statistical methods

The two types of communities sampled (C. aquatilis and small sedges) were analyzed separately because of their distinctly different structure and species composition. In each case, data were analyzed using mixed-model factorial ANOVAs (Kirk, 1982). Foraging, mainly shoot-pulling, was treated as a discontinuous fixed factor (exclosed plot or not), while "site" was treated as a random factor. All data were square-root transformed before analysis in order to stabilize variances (Cochran's C: $0.05>\mathrm{p}>0.01$ for 1 ANOVA; $\mathrm{p}>$ 0.05 in the remainder). To help compensate for varying sample sizes, these ANOVAs were supplemented with estimates of the "strength of association" statistic, $\omega^{2}$. This statistic is analogous to $r^{2}$ in a regression, indicating the proportion of experimental variance explained by a treatment (Kirk, 1982). Unlike variance components, $\omega^{2}$ is appropriate for a discontinuous fixed factor (Kirk, 1982). A time-series design was not used for two reasons. First, some plots were destroyed by polar bears, caribou and geese, so that the plots available differed on each occasion recordings were made, precluding the use of a balanced design. Second, observers, sampling areas, and the average size of the plots sampled differed on each occasion, suggesting it would be best to treat each year independently.

\section{Results}


Kotanen \& Jefferies: Long-term destruction by geese

Between 1986 and 1995, numbers of shoots in exclosed plots increased from 1.1 (small sedges) to 2.2 times (C. aquatilis), while numbers in non-exclosed plots declined to between 0.19 (small sedges) and 0.33 times (C. aquatilis) their original values (Figure 1). In 1986, densities of shoots did not differ significantly between non-exclosed and exclosed plots in either type of sedge assemblage (Table II), confirming that non-exclosed and exclosed plots initially were well matched; however, there were significant site effects, and a significant foraging x site interaction for C. aquatilis (Table II). Despite relatively small sample sizes, non-exclosed plots contained significantly fewer shoots than exclosures by 1989. By 1995, this difference was highly significant, in spite of foraging x site interactions (Figure 1; Table II).

In 1995, it was apparent that small $\left(<1 \mathrm{~m}^{2}\right)$ exclosures had survived much more successfully than large ones which often were damaged and contained droppings, pulled shoots, and other evidence of entry by geese and other animals. When large and small exclosures were analyzed separately, both analyses detected a significant and negative effect of shoot pulling in Carex aquatilis assemblages $\left(\mathrm{F}_{1,3}=27.28, \mathrm{p}<0.05\right.$ and $\mathrm{F}_{1,2}=$ 132.71, $\mathrm{p}<0.01$, respectively). In small sedge communities, shoot pulling significantly reduced shoot numbers in small, unprotected plots compared with numbers in small exclosures $\left(\mathrm{F}_{1,10}=309.68, \mathrm{p}<0.01\right)$, but there was no difference between large nonexclosed plots and large exclosures $\left(\mathrm{F}_{1,3}=9.75, \mathrm{p}>0.05\right)$ because of damage to the latter. Damage to both plot markers and exclosures made it difficult to identify unambiguously the sizes of some of the plots which were sampled in 1986 and 1989. However, since smaller exclosures indicated a stronger effect of herbivory than larger exclosures, our pre1995 results should be conservative both in 1986 (when mostly small exclosures were 
Kotanen \& Jefferies: Long-term destruction by geese

sampled and no effect of herbivory was detected) and in 1989 (when large exclosures were sampled and herbivory had a significant effect). These results strengthen the conclusion that herbivory initially had little effect, but that by 1989, strong differences had developed between exclosed and unprotected plots.

Power evidently was not a problem. After the first sampling, the effects of foraging were consistently significant and strength of association $\left(\omega^{2}\right)$ statistics indicated that foraging explained a large fraction of the overall variance (Table II). Frequent foraging $x$ site interactions indicate that magnitude of foraging effects differed from one location to the next, but because $\mathrm{MS}_{\text {foraging } \mathrm{x} \text { site }}$ was used as the error term, this does not alter the overall conclusion that foraging by geese produced an increasingly severe average reduction in densities of shoots, relative to similar values for exclosures.

\section{Discussion}

In spite of different observers, different sampling areas and destruction of exclosures over the decade, the deleterious effect of foraging and especially shoot-pulling of sedges by geese on shoot densities of these species is clearly evident. The results reflect exploitation of an annual resource pulse of nutrient-rich shoot bases by an expanding population of geese at a time of year when above-ground growth of biomass is very low or absent. Later, in the snow-free season, the nutritional value of the swollen shoot base declines as shoot growth occurs and resources are transferred to the mid- and upper sections of expanding shoots (Gadallah \& Jefferies, 1995). The exploitation of nutritional pulses characterizes arctic herbivory (Jefferies, Klein \& Shaver, 1994), where animals track the availability of high quality vegetation in space and time. The consequences for exploited 
Kotanen \& Jefferies: Long-term destruction by geese

plant populations can be severe. For example, the effects of muskox herbivory on the reproductive shoots of Oxytropis viscida early in the growing season may result in a decrease in the probability of flowering for a least two years following grazing (Mulder \& Harmsen, 1995). The effects of these resource exploitations on plant populations are cumulative and may be expected to lead to changes in assemblages of plant species.

This has occurred in areas immediately inland from La Pérouse Bay, where shootpulling has been intensive. In shallow ponds, where dense stands of Carex aquatilis were formerly present, the death of stands has created open ponds of standing water devoid of vegetation. Mixing of water by surface winds has resulted in increased mobility of large amounts of organic matter and peat debris. The system is dysfunctional and the depth and mobility of the debris appear to restrict germination and seedling establishment of wetland species. Muds are anoxic and some ponds have remained in this state for a decade or more. In saturated mossy areas, where small sedge assemblages formerly occurred, disappearance of sedges produces extensive moss carpets, in which only scattered shoots remain. Again, the thick moss layer appears to prevent seedling establishment. At some localities close to frost-heave mounds Salix reticulata and $S$. arctophila, together with Potentilla palustris and Petasites sagittatus, have grown across the moss carpet creating a new plant assemblage. The four latter species and the mosses appear not to be eaten by the geese, except in very small quantities (Jefferies, 1988a,b). This type of species assemblage can be recognized at a number of sites on the Cape Churchill peninsula, as well as other severely damaged goose colonies (Kerbes, Kotanen \& Jefferies, 1990) and is indicative of former disturbance by populations of geese. Which 
Kotanen \& Jefferies: Long-term destruction by geese

areas of vegetation are heavily affected by foraging activities of geese depends on snow melt patterns each year, both at local and regional levels.

Herbivores may interact with physical processes so that discontinuous and irreversible transitions in several stages of plant succession may occur (Westoby, Walker \& Noy Meir, 1989). Previously, Hik, Jefferies \& Sinclair (1992) described effects of grazing and grubbing by geese in modulating the direction of change in coastal salt-marsh vegetation over different time scales. This study extends earlier findings to include freshwater plant assemblages, where foraging activities of geese have led to multiple vegetation states, at least over an ecological time scale (10-15 years). In both open standing water and where moss carpets occur, the systems fail to return to their original vegetational states, probably reflecting both continuing foraging pressure and limitations on seedling establishment. This study also provides experimental support for the contention of Kerbes, Kotanen, \& Jefferies (1990) that grazing by geese has destroyed the fresh-water graminoid vegetation surrounding the more northerly McConnell River snow goose colony. In both cases, community development appears to have been irreversibly altered, at least over a time scale of 15 years.

\section{Acknowledgements}

We gratefully acknowledge the field assistance of members of the La Pérouse Bay Field Station. We thank the following organizations for financial support: Natural Sciences and Engineering Research Council, the Canadian Wildlife Service (Environment Canada), the Arctic Joint Goose Venture and the Department of Indian and Northern Affairs of the Government of Canada. Mrs. C. Siu kindly typed the manuscript. We thank Dr. R. 
Kotanen \& Jefferies: Long-term destruction by geese

Alisauskas and another reviewer for their helpful comments and suggestions which improved the manuscript. 
Kotanen \& Jefferies: Long-term destruction by geese

\section{Literature cited}

Abraham, K. F., R. L. Jefferies, R. F. Rockwell \& C. D. MacInnes, 199N. Why are there so many white geese in North America? J. Ratti (ed.). Proceedings of 7th International Waterfowl Symposium, Memphis, Tennessee, Feb. 4-6, 1996 (in press).

Alisaukas, R. T. \& C. D. Ankney, 1992. Winter diets and nutrition of mid-continental Lesser Snow Geese. Journal of Wildlife Management, 56: 43-54.

Cooke, F., R. F. Rockwell \& D. B. Lank, 1995. The Snow Geese of La Pérouse Bay. Oxford University Press, Oxford.

Gadallah, F. L. \& R. L. Jefferies, 1995. Comparison of the nutrient contents of the principal forage plants utilized by lesser snow geese on summer breeding grounds. Journal of Applied Ecology, 32: 263-275.

Hik, D. S., R. L. Jefferies \& A. R. E. Sinclair, 1992. Foraging by geese, isostatic uplift and asymmetry in the development of salt-marsh plant communities. Journal of Ecology, 80: 395-406.

Hobaugh, W. C., C. D. Stutzenbaker \& E. L. Flickinger, 1989. The rice prairies. Pages 367-383 in L. M. Smith, R. L. Pederson \& R. M. Kaminski (ed.). Habitat Management of Migrating and Wintering Waterfowl in North America. Texas Technical University Press, Lubbock, Texas.

Jefferies, R. L., 1988a. Vegetational mosaics, plant-animal interactions and resources for plant growth. Pages 340-361 in L. D. Gottieb \& S. K. Jain (ed.). Plant Evolutionary Biology. Chapman \& Hall, London. 
Kotanen \& Jefferies: Long-term destruction by geese

Jefferies, R. L., 1989b. Pattern and process in Arctic coastal vegetation in response to foraging by Lesser Snow Geese. Pages 281-300 in M. J. A. Werger, P. J. M. van der Aart, H. J. During \& J. T. A. Verhoeven (ed.). Plant Form and Vegetational Structure, Adaptation, Plasticity and Relationship to Herbivory. S. P. B. Academic Publishing, the Hague.

Jefferies, R. L., D. R. Klein, \& G. R. Shaver, 1994. Herbivory and northern plant communities: reciprocal influences and responses. Oikos, 71: 193-206.

Kerbes, R. H., P. M. Kotanen, \& R. L. Jefferies, 1990. Destruction of wetland habitats by Lesser Snow Geese: A keystone species on the west coast of Hudson Bay. Journal of Applied Ecology, 27: 242-258.

Kirk, R. E., 1982. Experimental Design, 2nd ed. Brooks \& Cole, Monterey, California.

Kotanen, P. M. \& R. L. Jefferies, 1989a. Responses of arctic sedges to release from grazing: Leaf demography of Carex Xflavicans. Canadian Journal of Botany, 67: 1408-1413.

Kotanen, P. M. \& R. L. Jefferies, 1989b. Response of arctic sedges to release from grazing: leaf elongation in two species of Carex. Canadian Journal of Botany, 67: 1414-1419.

Mulder, C. P. H. \& R. Harmsen, 1995. The effect of muskox herbivory on growth and reproduction in an arctic legume. Arctic \& Alpine Research, 27: 44-53.

Robertson, D. G. \& R. D. Slack, 1995. Landscape change and its effects on the wintering range of a lesser snow goose, Chen caerulescens caerulescens population: a review. Biological Conservation, 71: 179-185. 
Kotanen \& Jefferies: Long-term destruction by geese

Scoggan, H. J., 1978. The Flora of Canada. National Museum of Natural Sciences, Ottawa, Ontario.

Westoby, M., B. H. Walker \& I. Noy-Meir, 1989. Opportunistic management for rangelands not at equilibrium. Journal of Range Management, 42: 265-273. 
Kotanen \& Jefferies: Long-term destruction by geese

Table I. Sample sizes. All plots were established in 1985 or 1986

\begin{tabular}{|c|c|c|c|c|c|c|}
\hline Assemblage & Year & Treatment & $\begin{array}{c}\text { Plots } \\
\text { sampled }\end{array}$ & $\begin{array}{c}\text { Subplots/ } \\
\text { plot }\end{array}$ & $\begin{array}{l}\text { Area / subplot } \\
\qquad\left(\mathrm{cm}^{2}\right)\end{array}$ & $\begin{array}{c}\text { Total area } \\
\text { sampled }\left(\mathrm{cm}^{2}\right)\end{array}$ \\
\hline \multirow[t]{6}{*}{ C. aquatilis } & 1986 & exclosed & 6 & 4 & 156 & 3750 \\
\hline & & non-exclosed & 6 & 4 & 156 & 3750 \\
\hline & 1989 & exclosed & 5 & 3 & 100 & 1500 \\
\hline & & non-exclosed & 5 & 3 & 400 & 6000 \\
\hline & 1995 & exclosed & 7 & 3 & 100 & 2100 \\
\hline & & non-exclosed & 7 & 3 & 100 & 2100 \\
\hline \multirow[t]{6}{*}{ small sedges } & 1986 & exclosed & 5 & 10 & 25 & 1250 \\
\hline & & non-exclosed & 5 & 10 & 25 & 1250 \\
\hline & 1989 & exclosed & 4 & 3 & 100 & 1200 \\
\hline & & non-exclosed & 4 & 3 & 400 & 4800 \\
\hline & 1995 & exclosed & 15 & 3 & 100 & 4500 \\
\hline & & non-exclosed & 15 & 3 & 100 & 4500 \\
\hline
\end{tabular}


Kotanen \& Jefferies: Long-term destruction by geese

Table II. Results of mixed-model factorial ANOVAs examining the effects of foraging by geese and location on the number of shoots $\mathrm{cm}^{-2}$. "Foraging" (shoot-pulling) is a fixed factor, "site" is random. Also shown is $\omega^{2}$, a measure of foraging treatment strength.

\begin{tabular}{|c|c|c|c|c|c|}
\hline Assemblage & Year & Factor & $\mathrm{df}$ & MS & $\omega^{2}$ \\
\hline \multirow[t]{12}{*}{ Carex aquatilis } & \multirow[t]{4}{*}{1986} & foraging & 1 & 0.005 & \multirow[t]{4}{*}{0.000} \\
\hline & & site & 5 & 0.005 & \\
\hline & & foraging $\mathrm{x}$ site $†$ & 5 & $0.012 * *$ & \\
\hline & & residual $\ddagger$ & 36 & 0.002 & \\
\hline & \multirow[t]{4}{*}{1989} & foraging & 1 & $0.412 * *$ & \multirow[t]{4}{*}{0.670} \\
\hline & & site & 4 & $0.024 * *$ & \\
\hline & & foraging $\mathrm{x}$ site & 4 & $0.006^{*}$ & \\
\hline & & residual & 20 & 0.001 & \\
\hline & \multirow[t]{4}{*}{1995} & foraging & 1 & $0.785 * *$ & \multirow[t]{4}{*}{0.453} \\
\hline & & site & 6 & 0.027 & \\
\hline & & foraging $x$ site & 6 & $0.033 *$ & \\
\hline & & residual & 28 & 0.012 & \\
\hline \multirow[t]{12}{*}{ small sedges } & \multirow[t]{4}{*}{1986} & foraging & 1 & 0.000 & \multirow[t]{4}{*}{0.000} \\
\hline & & site & 4 & $0.087^{*}$ & \\
\hline & & foraging $\mathrm{x}$ site & 4 & 0.017 & \\
\hline & & residual & 90 & 0.028 & \\
\hline & \multirow[t]{4}{*}{1989} & foraging & 1 & $0.163 * *$ & \multirow[t]{4}{*}{0.516} \\
\hline & & site & 3 & $0.027 * *$ & \\
\hline & & foraging $\mathrm{x}$ site & 3 & $0.004^{*}$ & \\
\hline & & residual & 16 & 0.001 & \\
\hline & \multirow[t]{4}{*}{1995} & foraging & 1 & $1.916 * *$ & \multirow[t]{4}{*}{0.565} \\
\hline & & site & 14 & $0.048 * *$ & \\
\hline & & foraging $x$ site & 14 & $0.015^{*}$ & \\
\hline & & residual & 60 & 0.007 & \\
\hline
\end{tabular}

$\dagger$ error term for $\mathrm{F}_{\text {foraging }}$

$\ddagger$ error term for $\mathrm{F}_{\text {site }}$ and $\mathrm{F}_{\text {foraging } \mathrm{x} \text { site }}$

$* \mathrm{p}<0.05 ; * * \mathrm{p}<0.01$ 
Kotanen \& Jefferies: Long-term destruction by geese

\section{Figure Legends}

Fig. 1. Mean densities of shoots (+SEM). Results have been re-expressed as shoots $\mathrm{m}^{-2}$. Each pair of bars represents one site: filled bars = exclosures; stippled bars = grazed areas. For 1995 data, plot size (large or small) is also shown. See Table I, II for sample sizes and significance tests. 
Kotanen \& Jefferies: Long-term destruction by geese

Fig. 1
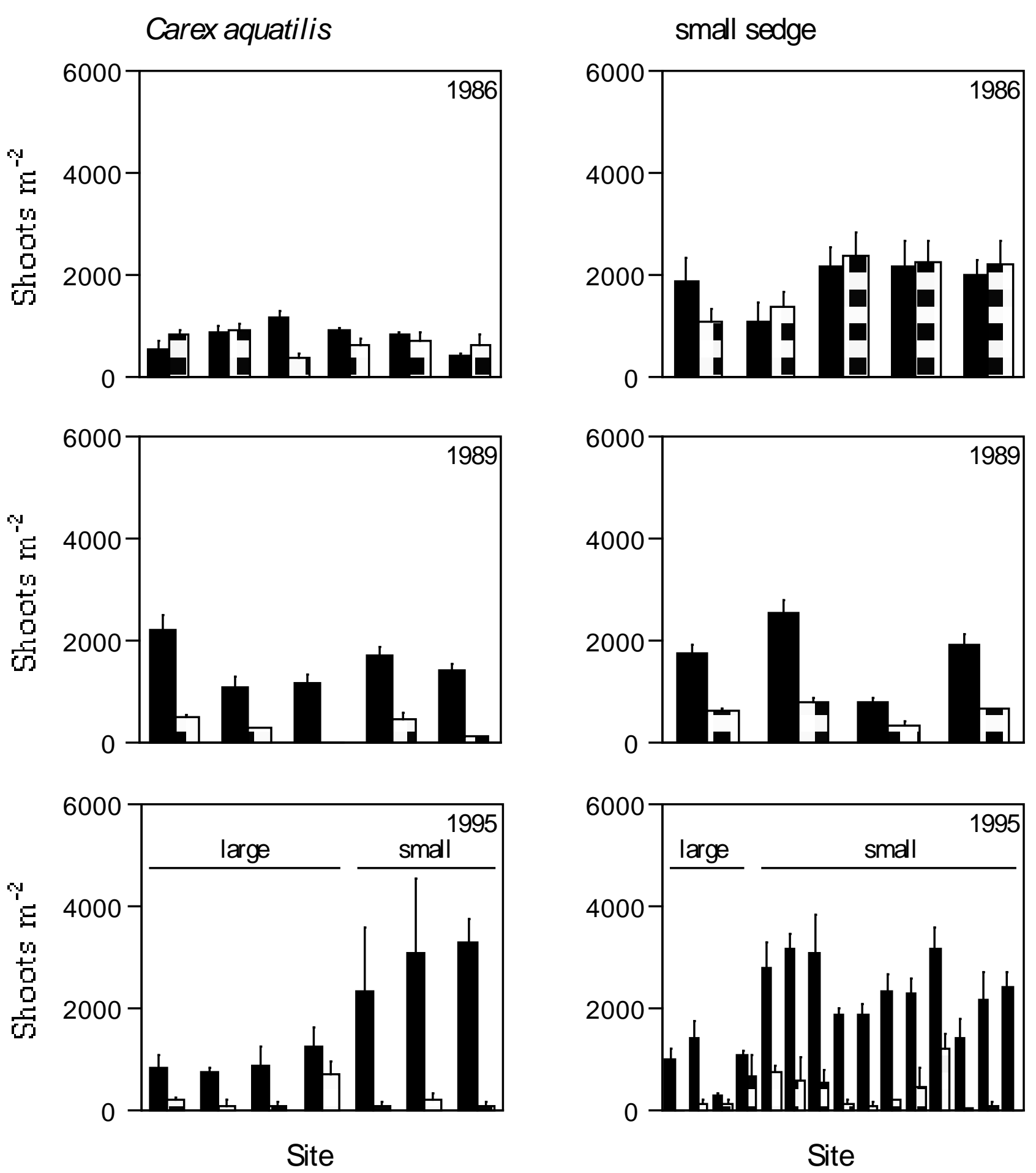